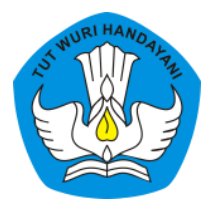

Page: 843-866

\title{
UPAYA MENINGKATKAN AKTIVITAS BELAJAR MATEMATIKA PESERTA DIDIK KELAS VII PADA PJJ MELALUI LEKSIMO
}

\author{
Nila Sari Latif \\ UPTD SMPN 9 Marusu Kabupaten Maros, Sulawesi Selatan, Indonesia \\ Contributor Email: nilalatif78@guru.smp.belajar.id
}

Received: Feb 15, 2021

Accepted: Oct 6, 2021

Published: Nov 30, 2021

Article Url: https://ojsdikdas.kemdikbud.go.id/index.php/didaktika/article/view/339

\begin{abstract}
The success of distance learning (PJJ) in mathematics requires teachers to be able to activate students in learning. This study was conducted to determine the increase in student activity in PJJ through using reflection sheets and emoji symbols in mathematics subjects through LKPD with Leksimo. This research is classroom action research, consisting of planning, action implementation, observation, and reflection stages in two cycles using LKPD with Leksimo. Research data were collected through observation and reflection sheets at the end of each cycle and then analyzed by qualitative and quantitative analysis. The results showed that the use of LKPD with Leksimo could activate students in the PJJ from the moderately active category with a percentage of $33.33 \%$ in the first cycle increasing to $58.33 \%$ with the active category in the second cycle. The emotional condition of students is very good in understanding and enthusiastic about doing assignments from $35.48 \%$ in the first cycle to $54.84 \%$ in the second cycle. Students who found obstacles or there was confusion in understanding assignments decreased from $25.81 \%$ to $6.45 \%$, which means that teachers can help students overcome obstacles to actively participate in learning with the emoji column on the LKPD. The increase in student activity was also marked by filling out the reflection sheet which showed an increase in parental control and supervision from $29 \%$ in cycle I to $71 \%$ in cycle II.
\end{abstract}

Keywords: Reflection Sheet; Emoji Symbol; Learning Activity. 


\begin{abstract}
Abstrak
Keberhasilan pembelajaran jarak jauh (PJJ) pada mata pelajaran matematika mengharuskan guru dapat mengaktifkan peserta didik dalam pembelajaran. Penelitian ini dilaksanakan untuk mengetahui peningkatan keaktifan peserta didik pada PJJ melalui pemanfaatan lembar refleksi dan simbol emoji pada mata pelajaran matematika melalui LKPD dengan Leksimo. Penelitian ini adalah penelitian tindakan kelas, terdiri dari tahapan perencanaan, pelaksanaan tindakan, observasi, dan refleksi pada dua siklus menggunakan LKPD dengan Leksimo. Data penelitian dikumpulkan melalui lembar observasi dan refleksi pada akhir setiap siklus kemudian dianalisis dengan analisis kualitatif dan kuantitatif. Hasil penelitian menunjukkan penggunaan LKPD dengan Leksimo dapat mengaktifkan peserta didik pada PJJ dari kategori cukup aktif dengan persentase sebesar 33,33\% pada siklus I meningkat menjadi 58,33\% dengan kategori aktif pada siklus II. Kondisi emosional peserta didik sangat baik dalam memahami dan bersemangat mengerjakan tugas dari 35,48\% pada siklus I menjadi 54,84\% pada siklus II. Peserta didik yang menemukan kendala atau kebingungan dalam memahami tugas menurun dari 25,81\% menjadi 6,45\%. Ini berarti guru dapat membantu peserta didik mengatasi hambatan untuk berpartisipasi aktif dalam pembelajaran dengan kolom emoji pada LKPD. Peningkatan keaktifan peserta didik juga tampak dari isian lembar refleksi yang menunjukkan peningkatan kontrol dan pengawasan orang tua dari $29 \%$ disiklus I menjadi $71 \%$ disiklus II.
\end{abstract}

Kata Kunci: Lembar Refleksi; Simbol Emoji; Aktivitas Belajar.

\title{
A. Pendahuluan
}

Sejak penyebaran Covid-19, pemerintah memberlakukan "New Era" yang berefek pada dunia pendidikan dimana tatap muka langsung dalam pembelajaran ditiadakan, bahkan sekolah-sekolah ditutup untuk kegiatan belajar mengajar. Salah satu kebijakan yang dilakukan pemerintah Indonesia dalam dunia pendidikan adalah dengan mengeluarkan Surat Edaran Nomor 4 Tahun 2020 tentang Pelaksanaan Kebijakan Pendidikan dalam Masa Darurat Penyebaran CoronaVirus Disease (Covid-19). Demi menghentikan penyebaran Covid-19 ini, semua peserta didik dan guru melakukan proses belajar dan mengajar dari rumah yang dikenal dengan istilah Pembelajaran Jarak Jauh (PJJ).

Penutupan sekolah bukan berarti harus menghentikan kegiatan pembelajaran. Pemberlakuan protokol kesehatan dengan menjaga jarak karena Covid-19 memberi hikmah, tantangan dan pengalaman luar biasa dalam pembelajaran. Karena Covid-19 terjadi proses adaptasi terhadap 
perubahan pola dan model pembelajaran yang mengintegrasikan TIK (Teknologi Informasi dan Teknologi) dalam pembelajaran. Peniadaan tatap muka dilakukan dengan model tatap muka jarak jauh (PJJ) meskipun model pembelajaran ini memang serasa tidak mudah. Perlu ada usaha-usaha ekstra dari guru untuk melakukan penyesuaian-penyesuaian dalam mengajar dengan tetap mengacu pada pencapaian indikator pembelajaran agar peserta didik tidak tertinggal dalam pembelajaran.

Proses integrasi TIK yang diterapkan untuk dapat melaksanakan kegiatan pembelajaran bagi peserta didik selama PJJ adalah dengan cara daring (dalam jaringan), dengan tetap menjaga mutu dan kualitas pembelajaran. Pelaksanaan PJJ dengan mengintegrasikan TIK sangat tepat digunakan untuk meningkatkan kualitas pembelajaran (Jauharul, 2016) yang berarti bahwa melalui PJJ, guru harus mampu menciptakan suasana pembelajaran daring yang menarik agar peserta didik dapat melaksanakan aktivitas pembelajaran seperti layaknya di dalam kelas konvensional atau secara tatap muka di dalam kelas.

Guru sebagai seorang fasilitator, perlu memfasilitasi peserta didik dalam pembelajaran daring dengan menggunakan beberapa platform seperti aplikasi Moodle, Google Classroom, WhatsApp, Zoom dan aplikasi lainnya, yang membutuhkan kemampuan guru untuk mendorong peserta didik agar dapat beraktivitas secara optimal dalam mencapai hasil belajar yang diinginkan. Google Classroom adalah salah satu aplikasi yang paling familiar yang useful dan mudah digunakan baik oleh guru maupun oleh peserta didik (Mahardini, 2020). Dengan sistem pembelajaran daring menggunakan Google Classroom, bukan berarti guru hanya memberikan tugas kepada peserta didik tanpa melibatkan aktivitas peserta didik disetiap tahapan pembelajaran karena bagaimanapun aktivitas peserta didik yang rendah pada PJJ akan berpengaruh terhadap hasil belajar yang diperoleh (Rizwan, 2016). Guru harus memastikan bahwa dengan platform pembelajaran daring apapun yang digunakan, kegiatan belajar-mengajar dan aktivitas belajar peserta didik tetap berjalan dengan baik melalui dorongan keaktifan untuk mencapai hasil belajar yang optimal (Suana, 2016). 
Pemanfaatan pembelajaran daring baik dengan menggunakan WhatAapp, Google Classroom maupun Zoom dapat membantu guru dalam mengecek kehadiran peserta didik, memberikan materi, tugas, evaluasi dan berinteraksi dengan peserta didik, meskipun dilakukan dalam keadaan daring. Guru dapat menyiasati penggunaan platform tersebut, agar dapat mengaktifkan peserta didik pada setiap tahapan pembelajaran. Meskipun disadari bahwa mengaktifkan peserta didik dalam pembelajaran daring memang memiliki kesulitan tersendiri karena sulitnya melakukan pemantauan secara langsung (Mahardini, 2020).

Kendala utama pelaksanaan pembelajaran daring adalah mengontrol dan mengawasi peserta didik dalam melaksanakan aktivitas pembelajarannya. Hal ini karena proses pembelajaran jarak jauh menjadikan guru tidak dapat secara langsung mengawasi peserta didik. Guru kesulitan mengaktifkan peserta didik dalam pembelajaran khususnya pada mata pelajaran matematika yang membutuhkan pengawasan dan pendampingan langsung guru pada saat peserta didik beraktivitas. Pada kenyataannya dalam pembelajaran daring, keaktifan peserta didik masih sangat rendah dan merupakan kendala utama dalam memantau peserta didik mengikuti seluruh rangkaian proses pembelajaran yang dilaksanakan. Kondisi ini memerlukan strategi untuk meningkatkan aktivitas peserta didik agar dapat mengikuti secara runtut proses pembelajaran dan dapat menuntaskan hasil belajarnya.

Sulitnya mengaktifkan peserta didik terutama dalam pembelajaran matematika juga menjadi kendala yang dihadapi pada pelaksanaan pembelajaran daring di kelas VII. Keaktifan peserta didik masih sangat rendah, meskipun dukungan infrastruktur jaringan internet cukup memadai yang dimiliki oleh peserta didik. Permasalahan tersebut sejalan dengan yang terjadi di lapangan bahwa pembelajaran daring yang dilaksanakan cenderung membuat peserta didik merasa bosan dan tidak memiliki minat belajar yang baik sehingga sulit mengaktifkan mereka dalam pembelajaran jarak jauh (Kristina dkk., 2020). Berdasarkan hasil wawancara dengan beberapa peserta didik, meningkatnya rasa bosan selama belajar matematika dari rumah adalah karena mereka merasa santai dalam belajar, tidak ada yang membimbing dan mengawasi dari dekat, waktu untuk mengerjakan 
tugas lebih lama. Mereka pada umumnya sebenarnya membutuhkan perhatian ketika ada permasalahan yang ditemukan saat mengerjakan tugas. Namun, mereka tidak bisa mengungkapkannya kepada guru secara langsung karena rasa malu dan tidak percaya diri. Dibutuhkan perhatian yang besar dari guru untuk membantu peserta didik dalam menghadapi hal tersebut, namun sayangnya masih ada guru yang kurang memberikan perhatian terhadap kondisi yang dialami peserta didik selama PJJ.

Strategi guru dituntut ketika keaktifan belajar matematika peserta didik semakin lama semakin menurun selama PJJ. Keaktifan peserta didik dalam belajar matematika yang sulit dikontrol guru menjadi salah satu kendala utama yang dihadapi guru. Akibatnya, terjadi ketidakefektifan kegiatan pembelajaran sehingga tidak semua peserta didik dapat mencapai hasil belajar matematika yang maksimal. Untuk meningkatkan aktivitas belajar peserta didik pada PJJ mata pelajaran matematika yang menggunakan refleksi diri sebagai pendekatan pedagogis menunjukkan bahwa (1) partisipasi dalam refleksi diri bervariasi menurut nilai, tingkat unjuk kerja unit tes, dan tingkat kesulitan topik dan (2) partisipasi peserta didik menunjukkan pengaruh hanya untuk topik yang lebih sulit (Choi dkk., 2017).

Kehadiran atau peran orangtua sangat diperlukan selama pembelajaran jarak jauh ini. Peran orangtua dibutuhkan dalam proses pengawasan atau memantau aktivitas belajar yang dilakukan peserta didik saat di rumah. Strategi pelibatan orangtua dalam mengontrol dan mengawasi aktivitas peserta didik selama belajar daring dapat dilakukan oleh guru dengan menggunakan lembar refleksi. Penelitian menunjukkan bahwa pembelajaran online dalam bentuk remedial dapat meningkatkan minat peserta didik dalam mengikuti kegiatan pembelajaran sehingga peserta didik dapat mencapai ketuntasan belajarnya (Nelyano, 2021). Agar pembelajaran jarak jauh dapat berlangsung dengan baik maka dibutuhkan peningkatan kesadaran akan pembelajarannya sendiri dan peningkatan kompleksitas keterampilan kognitif peserta didik sehingga dibutuhkan tahapan refleksi (Ong, 2000). Refleksi dibutuhkan untuk dapat mengetahui perkembangan dan aktivitas belajar peserta didik serta dapat melibatkan orang tua dalam mengontrol 
aktivitas belajar peserta didik. Pembelajaran online dengan refleksi, memungkinkan guru untuk mengevaluasi proses pembelajaran sebelumnya dan menjadi dasar untuk merancang pembelajaran selanjutnya serta dapat membantu peserta didik terlibat pembelajaran dan dalam siklus refleksi. (Oliver \& Herrington, 2002).

LKPD (student worksheet) yang dibuat oleh guru harus mengacu pada Kompetensi Dasar (KD) yang akan dicapai peserta didik. Bentuk dari LKPD berupa lembaran-lembaran berisi tugas, petunjuk, dan langkah-langkah untuk menyelesaikan tugas (Depdiknas, 2008). LKPD secara spesifik berisi materi, ringkasan, dan petunjuk-petunjuk pelaksanaan tugas pembelajaran yang harus dikerjakan oleh peserta didik dengan mengacu Kompetensi Dasar (KD) yang harus dicapai (Prastowo, 2012). Secara spesifik LKPD bertujuan untuk mengembangkan aspek kognitif maupun semua aspek pembelajaran dalam bentuk panduan kegiatan penyelidikan atau pemecahan masalah sesuai indikator pencapaian hasil belajar yang harus dicapai (Trianto, 2010). Selain itu, LKPD juga berfungsi untuk meningkatkan aktivitas peserta didik dalam belajar dan penggunaannya dalam pembelajaran dapat membantu guru untuk mengarahkan peserta didiknya menemukan konsep-konsep melalui aktivitasnya sendiri. Hasil penelitian menunjukkan bahwa penggunaan LKPD dapat meningkatkan keterampilan proses dan hasil belajar peserta didik (Khoiriah, 2019). Prinsip inilah yang mendasari pentingnya menggunakan LKPD dalam pembelajaran daring agar dapat mengembangkan keterampilan proses, meningkatkan aktivitas peserta didik dan dapat mengoptimalkan hasil belajar yang dilaksanakan secara mandiri oleh peserta didik.

Optimalisasi pemanfaatan LKPD dalam pembelajaran jarak jauh perlu dilengkapi dengan kolom respon dan refleksi agar guru dapat mengetahui kondisi dan keadaan peserta didik selama belajar mandiri dari rumah. LKPD yang dilengkapi dengan lembar refleksi orangtua disetiap pertemuan dapat memberikan informasi bagi guru untuk mengetahui kendala atau kesulitan yang sedang dihadapi peserta didik. Dalam proses belajar matematikanya. Selain itu, guru juga perlu memberikan perhatian besar terhadap kondisi emosional yang dialami peserta didik ketika melakukan 
aktivitas belajar matematika selama PJJ. Untuk melakukan pemantauan terhadap aktivitas belajar peserta didik dan mengetahui kondisi emosional serta tingkat capaian peserta didik setelah mengikuti pembelajaran matematika, maka kolom respon dan refleksi dibuat dalam bentuk lembar refleksi dan simbol emoji yang selanjutnya disebut dengan Leksimo.

LKPD yang dilengkapi dengan Leksimo, dapat menjadi strategi bagi guru untuk mengontrol dan mengawasi aktivitas belajar matematika peserta didik dan hasil belajar yang ingin dicapai melalui pelibatan orang tua pada saat peserta didik belajar di rumah dengan model PJJ. Selain LKPD, lembar refleksi dan simbol emoji (Leksimo) merupakan lembar kerja yang harus diselesaikan, baik oleh orangtua maupun peserta didik. Lembar refleksi berisi beberapa pertanyaan yang harus diisi oleh orangtua berdasarkan hasil pengawasannya terhadap aktivitas belajar matematika peserta didik, sedangkan simbol emoji yang memuat kolom pilihan emoji wajah harus dicentang oleh peserta didik sesuai dengan suasana hati atau kondisi emosional mereka saat menyelesaikan aktivitas pembelajaran matematikanya.

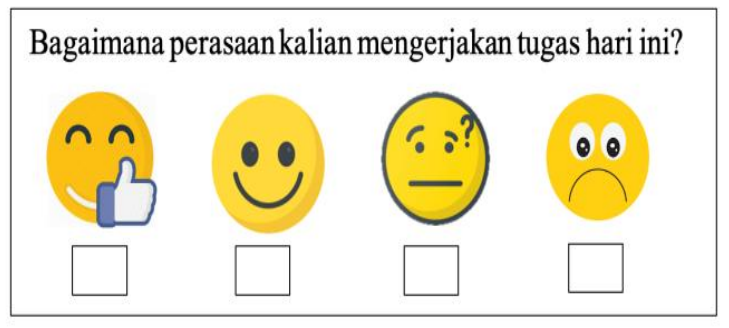

Gambar 1. Simbol Emoji Wajah pada LKPD

Simbol $\hat{3}$ artinya sangat baik dalam memahami dan sangat bersemangat mengerjakan tugas, simbol $\because$ artinya cukup baik dalam memahami tugas, simbol $\Theta$ artinya menemukan kendala atau ada kebingungan dalam memahami tugas atau materi, dan simbol $\bullet$ artinya sama sekali tidak memahami tugas atau materi yang diberikan.

Pemanfaatan simbol emoji sebagai pengganti isyarat nonverbal yang dapat melibatkan sosio-emosional seseorang pada saat membangun komunikasi jarak jauh. Penggunaan emoji pada LKPD akan melibatkan sosio-emosional peserta didik dalam merespon kegiatan PJJ. Dalam penggunaan simbol 
emoji terjadi proses reduced visibility dan reduced social presence yang dapat memperkuat aspek emosional, dibandingkan jika menggunakan bahasa verbal bahkan dengan emoji seseorang lebih mudah mengekspresikan emosinya (Pranata, 2014). Penggunaan emoji pada LKPD yang harus diisi peserta didik diharapkan dapat membantu peserta didik dalam mengekspresikan secara mudah kondisi emosional yang dihadapi saat melakukan aktivitas belajar matematika pada pembelajaran jarak jauh.

Selain kolom pilihan emoji, LKPD juga dilengkapi dengan lembar refleksi orangtua disetiap pertemuan sebagai alat bagi guru untuk mengetahui kontrol dan pengawasan orang tua terhadap aktivitas belajar peserta didik. Melalui kontrol ini, akan membantu guru dalam mendorong peserta didik untuk mengikuti seluruh tahapan pembelajaran daring. Dengan Leksimo diharapkan dapat memberikan motivasi baru bagi peserta didik untuk terlibat secara aktif berdasarkan instruksi yang disampaikan guru dan didukung oleh pengawaswan orangtua pada saat peserta didik melaksanakan pembelajaran.

Realitas menunjukkan bahwa kendala rendahnya frekuensi peserta didik yang beraktivitas secara sekuens sesuai langkah-langkah pembelajaran yang ditetapkan guru melalui aplikasi Google Classroom yang didukung dengan aplikasi Whatsapp Group (WaG) serta teleconfrence aplikasi Zoom pada mata pelajaran matematika yang diukur dari segi kehadiran, keaktifan pada setiap tahapan proses pembelajaran yang telah dirancang oleh guru, maupun dari segi ketepatan penyelesaian tugas perlu ditingkatkan agar peserta didik dapat menuntaskan hasil belajarnya. Untuk memecahkan masalah tersebut, maka dalam pembelajaran daring mata pelajaran matematika guru menggunakan LKPD dengan Leksimo agar peserta didik secara keseluruhan dapat melaksanakan aktivitas pembelajaran yang telah dirancang guru dalam pembelajaran daring melalui aplikasi Google Classroom. Untuk itu, penelitian ini akan menelusuri pemanfaatan lembar refleksi dan simbol emoji (Leksimo) sebagai upaya yang dilakukan guru untuk meningkatkan aktivitas belajar matematika peserta didik pada PJJ di kelas VII semester ganjil 2020/2021. 


\section{B. Metode}

Penelitian ini merupakan penelitian tindakan kelas (classroom action research) yang diadopsi dari model Kemmis dan McTaggart, terdiri dari perencanaan (planning), pelaksanaan tindakan (acting), observasi (observing), dan refleksi (reflecting). Penelitian ini dilaksanakan pada semester ganjil tahun ajaran 2020/2021 pada bulan Juli-Agustus 2020. Subjek penelitian ini adalah peserta didik sebanyak 31 orang dari kelas VII disalah satu sekolah di Kabupaten Maros dengan pertimbangan bahwa kelas VII memiliki aktivitas belajar matematika yang masih rendah selama PJJ.

Penelitian dilaksanakan sebanyak dua siklus di mana siklus kedua dilaksanakan berdasarkan hasil refleksi dari siklus pertama. Pada siklus II telah dilakukan perbaikan berdasarkan hasil refleksi pada siklus I yaitu dengan lebih mengaktifkan peserta didik dalam menggunakan LKPD menggunakan simbol emoji dan memberikan penekanan kepada orangtua peserta didik untuk aktif melakukan kontrol dan pengawasan melalui isian lembar refleksi. Selain menggunakan hasil refleksi pada siklus I, pelaksanaan siklus II juga menggunakan analisis hasil evaluasi pada siklus I sebagai pedoman untuk melaksanakan siklus II, yakni diadakan perbaikan tindakan yang menyebabkan hambatan ketercapaian sasaran pada siklus I.

Pengumpulan data penelitian menggunakan alat bantu dalam bentuk lembar observasi dan lembar refleksi yang diberikan pada akhir setiap siklus dengan berpedoman pada indikator keberhasilan penelitian yaitu peningkatan aktivitas belajar matematika peserta didik. Sesuai dengan jenis data yang akan dikumpulkan, analisis data penelitian dilakukan dalam dua jenis yaitu analisis kualitatif dan analisis kuantitatif. Teknik analisis data yang digunakan dalam penelitian ini menggunakan teknik analisis data deskriptif kualitatif dalam bentuk distribusi frekuensi dan persentase untuk mengetahui peningkatan jumlah peserta didik yang aktif dalam pembelajaran dengan menggunakan Leksimo. Sementara data hasil lembar refleksi dianalisis dengan cara mengumpulkan, mengklasifikasi, dan menginterpretasi kemudian melakukan sintesis terhadap hasil interpretasi peneliti.

Analisis data hasil observasi guru dan peserta didik pada kegiatan pembelajaran jarak jauh dinyatakan dalam persentase dengan menggunakan rumus: 


$$
\text { Nilai }(x)=\longdiv { \frac { \text { Skor Perolehan } } { \text { Skor Maksimal } } \times 1 0 0 }
$$

Untuk menentukan persentase aktivitas emosional pada pembelajaran jarak jauh menggunakan rumus berikut.

$$
\text { Nilai }(\mathrm{x})=\mid \frac{\text { frekuensi }}{\text { Jumlah siswa }} \times 100
$$

Nilai persentase yang diperoleh dari hasil observasi guru dan peserta didik pada kegiatan pembelajaran jarak jauh dianalisis menggunakan pedoman kriteria: Sangat Baik (76 $\leq x \leq 100)$, Baik (51 $\leq x \leq 75)$, Cukup Baik $(26 \leq x \leq 50$, dan Kurang Baik $(x \leq 25)$.

\section{Hasil dan Pembahasan}

\section{Hasil}

LKPD dengan Leksimo secara spesifik berisi materi, ringkasan, dan petunjuk-petunjuk pelaksanaan tugas pembelajaran yang harus dikerjakan oleh peserta didik dengan mengacu Kompetensi Dasar (KD) yang harus dicapai dengan mengintegrasikan lembar refleksi dan emoji (Leksimo) agar guru dan orangtua dapat memantau aktivitas belajar matematika peserta didik, serta untuk mengetahui hambatan dan kesulitan peserta didik dalam mengikuti kegiatan belajarnya selama PJJ. Melalui Leksimo, guru dapat membantu peserta didik mengatasi hambatan yang dihadapi selama PJJ berlangsung.

Hasil penelitian menunjukkan adanya peningkatan jumlah peserta didik yang beraktifitas sesuai tahapan pembelajaran yang telah dirancang oleh guru dalam bentuk PJJ melalui aplikasi Google Classroom. Kegiatan pembelajaran dilaksanakan sebanyak 2 kali pertemuan setiap siklus. Pelaksanaan Siklus I dilakukan dengan menggunakan LKPD yang dimodifikasi dalam bentuk Leksimo. Akan tetapi, hasil pembelajaran menunjukkan bahwa peserta didik belum aktif secara keseluruhan pada seluruh rangkaian kegiatan pembelajaran. Hal ini juga turut dipengaruhi oleh rendahnya kontrol dan pengawasan orang tua yang diketahui dari isian lembar refleksi. Karena kondisi tersebut, maka pada siklus II pembelajaran dilaksanakan dengan melakukan perbaikan dan peningkatan intensitas pengawasan 
orangtua melalui isian refleksi pada LKPD dengan Leksimo. Pada siklus II menunjukkan adanya progres positif keaktifan peserta didik secara keseluruhan pada setiap tahapan pembelajaran daring. Temuan penelitian ini menunjukkan bahwa peserta didik yang aktif dalam pembelajaran dapat ditingkatkan melalui LKPD dengan Leksimo yaitu lembar refleksi dan simbol emoji.

Keaktifan peserta didik dilihat dari aktivitas guru dalam melaksanakan kegiatan pembelajaran dan aktivitas peserta didik mengikuti seluruh tahapan pembelajaran jarak jauh. Data hasil penelitian yang diperoleh dari pelaksanaan observasi terhadap proses pembelajaran jarak jauh pada dua siklus ditunjukkan pada Tabel 1 berikut.

Tabel 1. Perbandingan Hasil Observasi terhadap Aktivitas Guru dalam PJJ pada Siklus I dan Siklus II

\begin{tabular}{|c|c|c|c|c|}
\hline \multirow{2}{*}{ No } & \multirow{2}{*}{\multicolumn{2}{|c|}{ Aspek yang di Amati }} & \multicolumn{2}{|c|}{ Skor } \\
\hline & & & Siklus I & Siklus II \\
\hline 1 & \multicolumn{2}{|c|}{ Kegiatan Pendahuluan } & 58 & 100 \\
\hline 2 & \multicolumn{2}{|c|}{ Kegiatan Inti } & 57 & 68 \\
\hline 3 & \multicolumn{2}{|c|}{ Evaluasi } & 50 & 75 \\
\hline 4 & \multicolumn{2}{|c|}{ Kegiatan Penutup } & 75 & 75 \\
\hline 5 & \multicolumn{2}{|c|}{ Suasana Kelas } & 69 & 75 \\
\hline & \multicolumn{2}{|c|}{ Total Skor Rata-Rata } & 42 & 52 \\
\hline & \multicolumn{2}{|c|}{ Nilai Aktivitas Guru } & \multirow[b]{2}{*}{$61,76 \%$} & \multirow[b]{2}{*}{$76,47 \%$} \\
\hline & Nilai $(x)=$ & $\frac{\text { Total Skor }}{68} \times 100$ & & \\
\hline & $\begin{array}{l}\text { Kriteria Pen } \\
\text { Kurang Bai } \\
\text { Cukup Baik } \\
\text { Baik } \\
\text { Sangat Baik }\end{array}$ & $\begin{array}{l}\text { laian (dalam } \%) \\
\quad: x \leq 25 \\
\quad: 26 \leq x \leq 50 \\
: 51 \leq x \leq 75 \\
: 76 \leq x \leq 100\end{array}$ & Baik & Sangat Baik \\
\hline
\end{tabular}

Tabel 1 menunjukkan bahwa rata-rata skor aktivitas guru pada PJJ dari siklus I sebesar $61,76 \%$ dengan kategori baik mengalami peningkatan pada siklus II sebesar 76,47\% dengan kategori sangat baik. Aktivitas guru pada PJJ pada siklus I masih berkategori baik karena guru belum memaksimalkan penggunaan LKPD dengan Leksimo sehingga masih terdapat peserta didik yang tidak aktif mengikuti seluruh kegiatan pembelajaran termasuk belum memaksimalkan refleksi dari orang tua peserta didik. Pada Siklus II, guru melakukan penekanan pada LKPD dengan menyertakan Leksimo tanpa mengubah tahapan pembelajaran, tetapi mengharuskan setiap peserta didik mengisi LKPD dengan Leksimo dan isian refleksi oleh orang tua 
sehingga berefek pada peningkatan skor aktivitas guru dalam pembelajaran jarak jauh dengan Google Classroom.

Data penelitian yang menunjukkan adanya peningkatan keaktifan peserta didik dalam belajar matematika pada PJJ diperoleh dari hasil observasi ditunjukkan pada Tabel 2 berikut ini.

Tabel 2. Perbandingan Hasil Observasi terhadap Keaktifan Peserta Didik dalam PJJ pada Siklus I dan Siklus II

\begin{tabular}{|c|c|c|c|}
\hline \multirow{2}{*}{ No } & \multirow{2}{*}{ Aktivitas yang diamati } & \multicolumn{2}{|c|}{ Skor Penilaian } \\
\hline & & Siklus I & Siklus II \\
\hline 1 & Mengisi absensi melalui Google Classroom & 2 & 3 \\
\hline 2 & $\begin{array}{l}\text { Mendengarkan/memperhatikan penjelasan guru melalui WaG, } \\
\text { Video Pembelajaran atau Zoom. }\end{array}$ & 2 & 3 \\
\hline 3 & $\begin{array}{l}\text { Aktif menjawab pertanyaan dari guru melalui WaG atau } \\
\text { Zoom }\end{array}$ & 1 & 2 \\
\hline 4 & Aktif bertanya kepada guru melalui WaG atau Zoom & 0 & 2 \\
\hline 5 & Menyimpulkan materi pembelajaran melalui WaG atau Zoom & 1 & 1 \\
\hline \multirow[t]{4}{*}{6} & $\begin{array}{l}\text { Mengerjakan dan menyerahkan tugas dengan Leksimo } \\
\text { melalui Google Classroom atau Wa }\end{array}$ & 2 & 3 \\
\hline & Total Skor & 8 & 14 \\
\hline & $\begin{array}{l}\text { Nilai Aktivitas Peserta Didik } \\
\text { Nilai }(x)=\frac{\text { Total Skor }}{24} x 100\end{array}$ & $33,33 \%$ & $58,33 \%$ \\
\hline & $\begin{array}{ll}\text { Kriteria Penilaian } & \text { (dalam } \%) \\
\text { Kurang Aktif } & : x \leq 25 \\
\text { Cukup Aktif } & : 26 \leq x \leq 50 \\
\text { Aktif } & : 51 \leq x \leq 75 \\
\text { Sangat Aktif } & : 76 \leq x \leq 100\end{array}$ & $\begin{array}{l}\text { Cukup } \\
\text { Aktif }\end{array}$ & Aktif \\
\hline
\end{tabular}

Tabel 2 menunjukkan bahwa skor penilaian keaktifan peserta didik mengalami peningkatan. Pada Siklus I keaktifan peserta didik masih berkategori cukup aktif yang ditunjukkan dari hasil observasi terhadap jumlah peserta didik belum seluruhnya hadir berpartisipasi mengikuti kegiatan PJJ melalui aplikasi Google Classroom. Hal ini diketahui dari skor peserta didik yang mengisi absensi, mengikuti penjelasan guru dan menyerahkan tugas. Suasana kelas juga belum tercipta dengan baik karena peserta didik belum mengemukakan pertanyaan melalui Whatsapp (WA) atau melalui teleconference via aplikasi Zoom. Kondisi pada siklus I tersebut dijadikan dasar untuk melakukan perbaikan melalui penggunaan LKPD dengan Leksimo yang diakses melalui Google Classroom. Setelah guru melakukan penekanan pada orang tua agar mengisi lembar refleksi dan kepada peserta didik agar penggunaan LKPD dengan simbol emoji 
harus dicentang pada setiap pertemuan, menunjukkan adanya peningkatan keaktifan peserta didik dalam PJJ melalui Google Classroom. Bahkan ditemukan bahwa jumlah peserta didik yang aktif berkomunikasi interaktif selama PJJ juga mengalami peningkatan.

Hasil analisis data penelitian menunjukkan bahwa keaktifan peserta didik yang diobservasi pada PJJ dengan Google Classrom mengalami peningkatan dari nilai skor keaktifan peserta didik sebesar 33,33\% pada siklus I menjadi $58,33 \%$ pada siklus II dengan kategori cukup aktif menjadi kategori Aktif. Peningkatan keaktifan peserta didik turut dipengaruhi oleh penggunaan simbol emoji pada LKPD yang diberikan kepada peserta didik untuk diisi disetiap akhir pelaksanaan pembelajaran pada Siklus II. Hasil isian lembar emoji untuk mengetahui aktivitas emosional melalui pemanfaatan LKPD dengan Leksimo pada setiap siklus ditunjukkan pada Tabel 3 berikut ini.

Tabel 3. Perbandingan Aktivitas Emosional Peserta Didik pada PJJ menggunakan Leksimo pada Siklus I dan Siklus II

\begin{tabular}{cllcccc}
\hline \multirow{2}{*}{ No } & \multicolumn{2}{c}{ Aktivitas Emosional } & \multicolumn{2}{c}{ Siklus I } & \multicolumn{2}{c}{ Siklus II } \\
\cline { 3 - 6 } & \multicolumn{1}{c}{$\mathrm{f}$} & $\%$ & $\mathrm{f}$ & $\%$ \\
\hline 1 & $\begin{array}{l}\text { Sangat } \\
\text { bersemangat mengerjakan tugas, }\end{array}$ & 11 & 35,48 & 17 & 54,84 \\
2 & $\begin{array}{l}\text { Cukup Baik dalam memahami tugas } \\
3\end{array}$ & $\begin{array}{l}\text { Menemukan kendala atau ada kebingungan } \\
\text { dalam memahami tugas dan materi, }\end{array}$ & 12 & 38,71 & 12 & 38,71 \\
4 & $\begin{array}{l}\text { Sama sekali tidak memahami tugas dan materi } \\
\text { yang diberikan }\end{array}$ & 0 & 0 & 0 & 0 \\
\hline & Jumlah & 31 & 100 & 31 & 100 \\
\hline
\end{tabular}

Tabel 3 menunjukkan bahwa peserta didik secara keseluruhan mengisi simbol emoji yang menggambarkan suasana emosional yang mereka rasakan selama menyelesaikan tugas menggunakan LKPD dengan Leksimo. Hasil distribusi frekuensi dan persentase menunjukkan adanya peningkatan aktivitas emosional peserta didik yang positif dalam mengerjakan tugas yang dikategorikan ke dalam empat level yaitu (1) sangat baik dalam memahami dan sangat bersemangat mengerjakan tugas, (2) cukup baik dalam memahami tugas, (3) menemukan kendala atau ada kebingungan dalam memahami tugas atau materi, dan (4) sama sekali tidak memahami tugas atau materi yang diberikan. Hasil analisis data pada 
siklus I, menunjukkan bahwa sebanyak 11 orang atau sebesar 35,48\% peserta didik yang sangat baik memahami dan bersemangat mengerjakan tugas, mengalami peningkatan pada siklus II menjadi 17 orang atau sebesar 54,84\%. Dengan demikian diketahui bahwa keaktifan peserta didik mengalami peningkatan karena kondisi emosional peserta didik berada dalam kondisi baik sehingga mereka bersedia berpartisipasi dalam kegiatan pembelajaran jarak jauh.

Data menunjukkan bahwa aktivitas emosional peserta didik yang merasa cukup baik dalam melaksanakan tugas juga mengalami peningkatan yang terlihat dari terjadinya penurunan persentase peserta didik yang merasa cukup baik dalam memahami tugas yaitu, terdapat 13 orang atau sebesar 40,32\% peserta didik pada siklus I mengalami penurunan pada siklus II yaitu sebanyak 12 orang atau sebesar 38,71\% yang berarti terjadi peningkatan kemampuan peserta didik memahami dengan baik materi dan tugas yang diberikan. Dari hasil analisis tersebut juga diperkuat oleh data bahwa terjadi penurunan yang signifikan jumlah peserta didik yang menemukan kendala atau ada kebingungan dalam memahami tugas dan materi yaitu dari 8 orang atau sebesar $24,19 \%$ menjadi 2 orang atau sebesar $6,45 \%$.

Peningkatan keaktifan peserta didik selain dipengaruhi oleh kondisi emosional mereka, juga karena adanya peningkatan kontrol orang tua selama kegiatan pembelajaran. LKPD yang diberikan guru kepada peserta didik melalui Google Classroom dilengkapi dengan lembar refleksi yang harus diisi oleh orang tua peserta didik setelah proses pembelajaran berlangsung sebagai kontrol kepada keaktifan peserta didik dalam mengikuti pembelajaran. Jadi, selama peserta didik belajar matematika, orang tua turut mendampingi dan memantau aktivitas belajar anaknya. Sehingga orang tua dapat mengisi lembar refleksi yang diberikan guru berdasarkan hasil pengamatan mereka. Data menunjukkan bahwa rata-rata jumlah orang tua yang mengirimkan lembar refleksi hasil observasi mereka terhadap keaktifan peserta didik dalam PJJ disajikan dalam Tabel 4. 
Tabel 4. Persentase Keterlibatan Orangtua Mengisi Lembar Refleksi dalam PJJ pada Siklus I dan Siklus II

\begin{tabular}{lcc}
\hline & Siklus 1 & Siklus 2 \\
\hline $\begin{array}{l}\text { Rata-rata jumlah orang tua yang mengirimkan lembar refleksi } \\
\text { (orang) }\end{array}$ & 9 & 22 \\
\hline Persentase (\%) & 29 & 71 \\
\hline
\end{tabular}

Berdasarkan Tabel 4 diketahui bahwa terjadi peningkatan jumlah orang tua peserta didik yang memberikan refleksi kepada guru dari aktivitas pembelajaran jarak jauh yang diikuti oleh peserta didik melalui google classroom. Hal ini diketahui dari hasil perolehan dari jumlah lembar refleksi yang diserahkan orang tua peserta didik pada siklus I ratarata sebanyak 9 orang atau sebesar 29\% mengalami peningkatan pada siklus II yaitu rata-rata sebanyak 22 orang atau sebesar $71 \%$.

Hasil refleksi yang diserahkan orangtua setelah di analisis dengan menggunakan analisis kualitatif dengan cara mengumpulkan, mengklasifikasi dan menginterpretasi isian lembar refleksi diketahui bahwa pada umumnya aktivitas belajar matematika peserta didik dalam PJJ cukup aktif. Hasil refleksi yang disampaikan orang tua pada umunya menginformasikan (1) peserta didik pada umumnya telah mengikuti seluruh kegiatan pembelajaran dengan baik mulai dari tahapan pendahuluan sampai kegiatan evaluasi; (2) peserta didik pada umumnya dapat memahami sebagian besar materi dan tugas yang diberikan oleh guru, meskipun beberapa peserta didik masih kesulitan karena membutuhkan bimbingan langsung dari guru; (3) masih terdapat peserta didik yang memahami materi tetapi masih kurang mengerti cara menyelesaikan tugas yang diberikan; dan (4) beberapa peserta didik yang kesulitan memahami materi terbantu dengan video pembelajaran yang sediakan oleh guru. Hasil isian refleksi orang tua peserta didik menjadi dasar untuk melakukan perubahan pembelajaran pada siklus II. Dari hasil refleksi pada siklus II informasi yang diberikan orang tua pada umumnya masih sama, akan tetapi jumlah peserta didik yang mengalami hambatan belajar matematika dalam pembelajaran jarak jauh melalui Google Classroom sudah mengalami penurunan. 


\section{Pembahasan}

Pemanfaatan LKPD yang dimodifikasi menjadi LKPD dengan Leksimo memiliki keuntungan lebih pada saat pelaksanaan pembelajaran jarak jauh dengan Google Classroom WaG, maupun Zoom. LKPD yang telah dimodifikasi tersebut menyertakan simbol wajah emoji, memberikan kesempatan bagi peserta didik menginformasikan kepada guru tentang perasaan mereka saat menerima materi dan mengerjakan tugas yang diberikan pada PJJ. Pengisian LKPD dengan simbol emoji juga menjadi alat bagi guru untuk mengetahui apakah peserta didik siap secara emosional mengikuti kegiatan pembelajaran shingga mereka dapat berpartisipasi aktif mengikuti kegiatan pembelajaran secara daring.

Hasil penelitian tentang penggunaan Leksimo menunjukkan adanya peningkatan aktivitas belajar matematika peserta didik di kelas VII yang dilaksanakan dalam bentuk PJJ melalui aplikasi Google Classroom, WaG maupun aplikasi Zoom. Peningkatan ini diperoleh dari pelaksanaan kegiatan pembelajaran yang dilakukan sebanyak 4 kali pertemuan dari 2 siklus.

Keaktifan peserta didik pada Siklus I meskipun guru telah menggunakan LKPD dengan Leksimo, belum menunjukkan adanya peningkatan keaktifan peserta didik mengikuti tahapan pembelajaran. Hal ini disebabkan karena peserta didik masih bingung dalam memahami tugas dan materi yang diberikan oleh guru. Kondisi emosional peserta didik mempengaruhi keaktifan mereka dalam pembelajaran. Pada umumnya kondisi emosional peserta didik di awal pembelajaran jarak jauh masih membutuhkan perhatian yang lebih dari guru. Hal ini karena dari isian kolom emoji pada LKPD masih lebih banyak peserta didik yang mengisi simbol emoji $\because$ yang berarti peserta didik menemukan kendala atau ada kebingungan dalam memahami tugas atau materi yang diberikan oleh guru.

Rendahnya keaktifan peserta didik pada siklus I juga dipengaruhi oleh rendahnya pantauan dan pengawasan orang tua dalam mendampingi peserta didik belajar di rumah. Hal ini diperoleh dari jumlah orang tua yang mengisi kolom refleksi pada LKPD terkait keaktifan dan kondisi emosional peserta didik pada saat mengikuti kegiatan pembelajaran. Rendahnya keaktifan 
peserta didik pada siklus I juga menunjukkan suasana kelas belum efektif karena peserta didik belum berinteraksi dalam kelas virtual, baik melalui aktivitas tanya jawab melalui WhatsApp (WA) atau melalui teleconference via aplikasi Zoom.

Refleksi terhadap kondisi pembelajaran pada siklus I, menjadi dasar perbaikan pembelajaran pada siklus II. Langkah pertama yang dilakukan guru adalah dengan memberikan respon terhadap isian simbol pada kolom emoji $\because$ yang diserahkan oleh peserta didik. Jika peserta didik mencentang emoji $\ddot{\bullet}$, tindakan yang dilakukan guru adalah dengan melakukan komunikasi secara pribadi melalui WA atau video call. Bagi peserta didik yang mencentang emoji, guru tetap memberikan perhatian dalam bentuk penguatan dan motivasi belajar agar mereka tetap aktif mengikuti seluruh tahapan kegiatan pembelajaran.

Langkah kedua adalah dengan menganalisis isian kolom refleksi pada LKPD yang difokuskan pada hambatan dan kendala yang menyebabkan peserta tidak aktif dalam pembelajaran untuk menjadi dasar tindakan yang akan dilakukan oleh guru. Berdasarkan hasil refleksi orang tua diketahui bahwa (1) peserta didik pada umumnya masih membutuhkan bimbingan langsung dari guru untuk menyelesaikan tugas yang diberikan dan (2) peserta didik kesulitan memahami materi yang sediakan oleh guru. Tindakan guru terhadap hasil isian kolom refleksi adalah dengan melakukan bimbingan langsung melalui video tutorial, video call bagi peserta didik yang kesulitan menyelesaikan tugas yang diberikan dan bagi peserta didik yang kesulitan memahami materi pelajaran.

Perbaikan kelemahan penggunaan LKPD dengan Leksimo pada siklus I dan tindakan guru terhadap hasil isian leksimo baik oleh peserta didik dan orang tua menunjukkan hasil positif pada siklus II. Keaktifan peserta didik pada siklus II mengalami peningkatan dimana peserta didik lebih banyak yang aktif dalam pembelajaran seperti pengisian absensi online oleh seluruh peserta didik, mendengarkan atau memperhatikan penjelasan guru, beberapa peserta didik telah berani bertanya dan menjawab pertanyaan dari guru, menyimpulkan materi pembelajaran, serta mengerjakan dan menyerahkan tugas matematika. Keaktifan tersebut karena guru telah merespon dengan cepat hambatan yang dihadapi peserta didik yang 
diketahui dari lembar emoji yang dipilih oleh peserta didik. Guru membantu peserta didik mengatasi hambatan yang mereka hadapi melalui komunikasi via Zoom atau menggunakan aplikasi WA. Bahkan ditemukan bahwa jumlah peserta didik yang berkomunikasi interaktif terhadap teman sejawatnya, selama PJJ juga mengalami peningkatan.

Hasil perbaikan pada pembelajaran dalam bentuk pemberian respon yang cepat oleh guru terhadap simbol emoji dan isian refleksi orang tua menyebabkan terjadinya peningkatan keaktifan peserta didik dalam pembelajaran. Hasil penelitian ini menunjukkan bahwa melalui lembar emoji jumlah peserta didik yang aktif mengikuti kegiatan pembelajaran mengalami peningkatan. Hal ini karena melalui lembar emoji dapat secara spontan memudahkan peserta didik membangun komunikasi efektif dengan guru melalui ekspresi perasaan mereka dengan simbol emoji sehingga guru dapat segera merespon hambatan yang dihadapi peserta didik. Peserta didik dapat mengekspresikan kondisi emosional mereka melalui simbol emoji karena dengan simbol emoji seseorang lebih mudah menggambarkan keadaan mereka yang sebenarnya (Tanimu \& Abdullah, 2013). Hal ini dapat menjadi bahan utama bagi guru untuk dapat menetapkan strategi pembelajaran agar peerta didik secara keselurahan dapat berpartisipasi secara aktif dalam pembelajaran.

Keberhasilan guru dalam meningkatkan keaktifan peserta didik harus dilakukan dengan memperhatikan perencanaan guru dalam melaksanakan pembelajaran jarak jauh menggunakan aplikasi Google Classroom di antaranya adalah dengan menambahkan lembar emoji yang harus segera direspon sebagai langkah untuk memecahkan masalah peserta didik. Keberhasilan guru dalam mendesain tahapan pembelajaran dapat memudahkan peserta didik untuk melibatkan diri dalam setiap tahapan pembelajaran. Kondisi ini perlu diperhatikan dalam melaksanakan pembelajaran jarak jauh, karena salah satu hambatan utama penggunaan Google Classroom dalam PJJ adalah karena sulitnya mengaktifkan peserta didik dalam seluruh tahapan pembelajaran yang sudah didesain oleh guru (Mahardini, 2020). Pemberian tugas peserta didik melalui Google Classroom yang diberikan dalam bentuk LKPD dengan Leksimo, keaktifan peserta didik dapat ditingkatkan karena guru dapat 
menetapkan batas waktu penyelesaian dan penyetoran tugas, sehingga mendorong keaktifan peserta didik (Tafrilyanto dkk., 2020).

LKPD yang dimodifikasi dengan menambahkan kolom emoji yang dapat diisi oleh peserta didik dengan beberapa simbol yang menggambarkan keadaan mereka dapat membantu guru merencanakan tindakan pembelajarannya. Contohnya, jika peserta didik berhasil dan menyenangkan dalam belajar, guru dapat mempertahankannya. Namun, jika peserta didik masih tidak menyukainya, berarti guru harus segera mengubah model pembelajaran dengan menggunakan metode atau teknik yang sesuai dan dapat memudahkan peserta didik memahami materi pelajaran. Kondisi emosional peserta didik dalam pembelajaran jarak jauh dapat diketahui guru karena dengan emoji, peserta didik dapat menggambarkan secara tepat kondisi perasaan mereka terhadap materi (Pranata, 2014). Penggunaan simbol emoji pada LKPD yang dikerjakan oleh peserta didik untuk mengetahui kondisi emosional pada saat belajar matematika dan mengerjakan tugas LKPD terdiri atas beberapa kriteria. Sebagai contoh adalah kriteria sangat baik dalam memahami dan sangat bersemangat mengerjakan tugas, cukup baik dalam memahami tugas, menemukan kendala atau ada kebingungan dalam memahami tugas dan materi, serta sama sekali tidak memahami tugas dan materi yang diberikan. Semakin baik kondisi emosional peserta didik,semakin siap mereka untuk terlibat berpartisipasi dalam kegiatan pembelajaran jarak jauh.

Manfaat lain yang diperleh dari penggunaan simbol emoji yaitu guru dapat memperoleh informasi positif tentang kondisi emosional peserta didik untuk menjadi masukan bagi guru dapat meningkatkan kualitas pembelajaran, serta menjadi bahan observasi untuk mengetahui sejauh mana hasil belajar yang dicapai oleh peserta didik setelah kegiatan pembelajaran berlangsung. Selain itu, kegiatan ini dapat membawa kepuasan peserta didik dan tempat yang tepat untuk menjalin komunikasi positif antara orangtua dengan guru melalui pemanfaatan lembar refleksi orangtua peserta didik dalam memantau dan mengobservasi kegiatan pembelajaran peserta didik 
selama PJJ. Jadi, dengan lembar refleksi guru dapat menfasilitasi hubungan positif antara peserta didik, guru dan orang tua peserta didik (Cahyati \& Kusumah, 2020).

Temuan penelitian lainnya adalah peningkatan keaktifan peserta didik dalam PJJ juga terjadi karena keterlibatan orang tua dalam mendampingi peserta didik untuk mengikuti PJJ. Hal ini diketahui dari hasil isian lembar refleksi orang tua terhadap kondisi peserta didik selama mengikuti kegiatan pembelajaran. Dengan refleksi dari orang tua, guru dapat mengetahui kondisi peserta didik selama pembelajaran, hambatan yang mereka hadapi, dan materi apa yang tidak dapat dikuasai atau dipahami oleh peserta didik. Temuan ini sejalan dengan hasil penelitian yang menekankan pentingnya peran orang tua mengontrol dan mengawasi kegiatan yang dilakukan selama PJJ, memotivasi anak didik dalam belajar, dan mengembangkan kemampuan belajar anak serta memberikan informasi tentang kondisi peserta didik selama pembelajaran berlangsung. Pencapaian tersebut diperoleh dari penggunaan LKPD yang dimodifikasi menjadi Leksimo agar orang tua selain dapat meningkatkan kualitas hubungan dengan anaknya juga dapat mengetahui perkembangan kemampuan anaknya dalam belajar (Cahyati \& Kusumah, 2020).

Selama penggunaaan Leksimo dalam penelitian ini, lembar refleksi orang tua membantu guru memantau aktivitas belajar daring peserta didik di rumah sehingga guru dapat memperoleh informasi gap antara target pembelajaran dengan capaian peserta didik setelah mengikuti PJJ. Hasil refleksi orang tua yang diserahkan kepada guru dapat menjadi dasar pertimbangan guru untuk memperbaiki kualitas pembelajaran berikutnya. Menurut Richards \& Lockhart (2007), kebutuhan refleksi dalam pengajaran, akan membantu guru menemukan gap antara apa yang mereka ajarkan dengan apa yang peserta didik pelajari. Guru akan mendapatkan pengetahuan yang mendalam mengenai pengajarannya dengan proses pencarian di kelasnya masing-masing (self-inquiry). Penelitian ini telah memberikan informasi pada guru tentang kondisi jumlah peserta didik yang memperoleh hambatan dalam menyelesaikan tugas, jumlah peserta didik yang tidak aktif mengikuti seluruh kegiatan pembelajaran dan jumlah peserta 
didik yang tidak memahami secara keseluruhan materi yang disampaikan selama PJJ. Semua informasi itu diperoleh berkat lembar refleksi yang dikirimkan oleh orang tua peserta didik.

Penggunaan LKPD yang dilengkapi dengan Leksimo selama PJJ di salah satu sekolah di Kabupaten Maros berdasarkan hasil penelitian menunjukkan adanya peningkatan keaktifan peserta didik dalam pembelajaran matematika pada setiap tahapan kegiatan pembelajaran yang dilaksanakan sekuens, yaitu kegiatan pendahuluan, kegiatan inti, evaluasi dan kegiatan penutup. Di samping itu, manfaat yang dirasakan oleh guru dengan menggunakan Leksimo adalah dapat mengetahui keaktifan peserta didik, membangun komunikasi efektif dengan peserta didik dan orang tua, mengevaluasi cara, dan pendekatan pembelajaran yang digunakan, penggunaan metode atau model pembelajaran yang sesuai, serta dapat menemukan kesulitan yang dihadapi peserta didik dalam memahami materi atau tugas matematika yang diberikan. Komunikasi efektif terbangun melalui penggunaan simbol yang merupakan bentuk penggambaran ekspresi wajah seseorang sebagai representasi grafis dan animasi dari beragam elemen (Tanimu \& Abdullah, 2013).

Penggunaan Leksimo pada LKPD secara tidak langsung menjadi instrumen untuk aktivitas peserta didik serta membangun kerjasama dengan orang tua dalam mengontrol dan mendampingi peserta didik belajar secara daring. Secara spesifik, penelitian ini menunjukkan bahwa selama PJJ, aktivitas belajar matematika peserta didik yang diobservasi mengalami peningkatan dilihat dari nilai skor aktivitas belajar peserta didik yang meningkat dari siklus I ke siklus II sebesar 25\% (Siklus II = 58,33\% - Siklus $\mathrm{I}=33,33 \%)$ dengan kategori aktif. Kondisi emosional peserta didik juga menunjukkan peningkatan bahwa sebanyak $54,58 \%$ peserta didik sangat baik dalam memahami dan sangat bersemangat mengerjakan tugas melalui LKPD Leksimo. Dengan meningkatnya kondisi emosional peserta didik dan kegiatan belajar matematika peserta didik yang semakin aktif membawa perubahan pada proses PJJ. Dengan demikian, diharapkan kualitas pembelajaran jarak jauh dan hasil belajar matematika peserta didik semakin baik kedepannya. 


\section{Penutup}

Pembelajaran jarak jauh menggunakan aplikasi Google Classroom memerlukan strategi untuk dapat memantau keaktifan peserta didik dalam pembelajaran matematika agar dapat mencapai tujuan pembelajaran yang telah ditetapkan. Hasil penelitian menunjukkan bahwa penggunaan LKPD dengan Leksimo dapat meningkatkan keaktifan peserta didik dalam kegiatan pembelajaran jarak jauh. Peningkatan keaktifan peserta didik dapat dicapai karena melalui Leksimo guru dapat mengambil tindakan terhadap hambatan belajar yang dihadapi peserta didik yang disampaikan melalui lembar emoji yang juga diperkuat dengan hasil refleksi orang tua. Pemahaman guru terhadap kondisi emosional peserta didik yang diperoleh dari isian lembar emoji menjadikan guru dapat mengelola kelas virtual menjadi lebih efektif serta dapat mendorong peserta didik untuk aktif selama pelaksanaan PJJ dengan memberikan solusi terhadap hambatan dan kesulitan yang dihadapi peserta didik selama mengikuti PJJ. Pemanfaatan LKPD dengan lembar refleksi orang tua membantu guru dalam mengontrol dan mengawasi keaktifan belajar peserta didik selama proses pembelajaran jarak jauh. Untuk itu, maka pemanfaatan Leksimo (Lembar refleksi dan Simbol emoji) pada LKPD akan membantu guru dan orang tua dalam memantau peserta didik untuk lebih aktif mengikuti kegiatan pembelajaran dengan membantu memecahkan hambatan pembelajaran yang dihadapi peserta didik.

Hasil penelitian ini menegaskan bahwa untuk mengaktifkan peserta didik dalam pembelajaran jarak jauh, perlu menggunakan LKPD dengan Leksimo agar guru dapat mengetahui hambatan peserta didik diantaranya hambatan emosional, kesulitan memahami materi dan tugas dan hambatan lainnya, sehingga guru dapat mengambil tindakan untuk membantu peserta didik dalam menyelesaikan hambatan tersebut.

\section{Daftar Referensi}

Abtahi, M., \& Battell, C. (2017). Integrate Social Justice Into the Mathematics Curriculum in Learning. Jurnal Ilmiah Peuradeun, 5(1), 101-114. doi:10.26811/ peuradeun.v5i1.123 
Anim, A., Prasetyo, Y., \& Rahmadani, E. (2019). Experimentation of Problem Posing Learning Model Assisted of Autograph Software to Students' Mathematical Communication Ability in Terms of Student's Gender. Jurnal Ilmiah Peuradeun, 7(2), 331-342. doi:10.26811/peuradeun.v7i2.301

Cahyati, N., \& Kusumah, R. (2020). Peran Orang Tua dalam Menerapkan Pembelajaran di Rumah Saat Pandemi Covid 19. Jurnal Golden Age, 4(1), 152-159.

Choi, J., Walters, A., \& Hoge, P. (2017). Self-Reflection and Math Performance in an Online Learning Environment. Online Learning Journal, 21(4), 79-102. http://dx.doi.org/10.24059/olj.v21i4.1249

Depdiknas. (2008). Panduan Pengembangan Bahan Ajar. Dirjen Pendidikan Dasar dan Menengah.

Fonna, M., \& Mursalin, M. (2018). Role of Self-Efficacy Toward Students' Achievement in Mathematical Multiple Representation Ability (MMRA). Jurnal Ilmiah Peuradeun, 6(1), 31-40. doi:10.26811/peuradeun.v6i1.174

Jauharul, F., Muhammad. (2016). Pengembangan Aplikasi Evaluasi Pembelajaran Online untuk Pendidikan Jarak Jauh. Jurnal Tekno, 26(2), 148-154.

Khoiriah, K. (2019). Peningkatan Keterampilan Proses Sains dan Hasil Belajar Peserta Didik melalui Penerapan Lembar Kerja Peserta didik Berbasis Penemuan. Jurnal Didaktika Pendidikan Dasar. Jurnal Didaktika Pendidikan Dasar, 3(2), 551-568.https://ojsdikdas.kemdikbud.go.id/index.php/didaktika/index

Kristina, M., Sari, R. N., \& Nagara, E. S. (2020). Model Pelaksanaan Pembelajaran Daring pada Masa Pandemi Covid-19 di Provinsi Lampung. 4(2), 200209. https:// doi.org/10.24252/idaarah.v4i2.16945

Mahardini, M. M. A. (2020). Analisis Situasi Penggunaan Google Classroom pada Pembelajaran Daring Fisika. Jurnal Pendidikan Fisika Universitas Muhammadiyah Metro, 8(2), 215-224. http://dx.doi.org/10.24127/jpf.v8i2.3102

Nelyano, A. U. (2021). Increasing Student Interest in Learning with Online Remedial Teaching Using Google Drive. Jurnal Didaktika Pendidikan Dasar, 4(1), 143-150. https://doi.org/10.26811/didaktika.v4i1.154

Oliver, R., \& Herrington, J. (2002). Designing for reflection in online courses. ECU Publications. 
Ong, R. (2000). The role of reflection in student learning: A study of its effectiveness in complementing problem-based learning environments.

Pranata, A. (2014). Ekspresi Emosi Melalui Computer Mediated Communication Pada Pengguna Social Network Sites di Kota Surabaya. Jurnal eKomunikasi, 4(2), 1-13.

Prastowo, A. (2012). Panduan Kreatif Membuat Bahan Ajar Inovatif. Diva Press.

Richards, J. C., \& Lockhart, C. (2007). Reflective teaching in second language classrooms / Jack C. Richards and. (15th ed.). Cambridge University Press.

Rizwan. (2016). Meningkatkan Aktivitas dan Hasil Belajar Peserta Didik dalam Belajar IPA melalui Pembelajaran Kontekstual. Jurnal Educatio, 2(1), 11-20. https://doi.org/10.29210/12016227

Suana, W. (2016). Peningkatan Aktivitas dan Hasil Belajar Peserta didik pada Pembelajaran IPA dengan Pendekatan Keterampilan Proses. Jurnal Ilmiah Fisika Al-Biruni, 5(1), 5-22. https://doi.org/10.24042/jpifalbiruni.v5i1.101

Tafrilyanto, C. F., Lanya, H., \& Zayyadi, M. (2020). Desain Pembelajaran Statistik Melalui Google Classroom. Jurnal Pembelajaran Matematika Inovatif, 3(6), 653-662. https:// doi.org/10.22460/jpmi.v3i6.653-662

Tanimu, A. J., \& Abdullah, M. H. (2013). Relevance of Emoticons in ComputerMediated Communication Contexts: An Overview. Canadian Center of Science and Education, 9(4). https://doi.org/10.5539/ass.v9n4p201

Trianto. (2010). Model Pembelajaran Terpadu, Konsep, Strategi dan Implementasinya dalam KTSP. Bumi Aksara. 